\title{
Water Related Poverty among Farm Households in Ebonyi State, Nigeria
}

\author{
Ufiem O.O ${ }^{1}$, Umeh G.N², Alimba J.O ${ }^{3}$ \\ ${ }^{1}$ Ebonyi State Secondary Education Board, Abakaliki, Ebonyi State, Nigeria. \\ ${ }^{2,3}$ Department of Agricultural Economics, Management and Extension Ebonyi State University, P.M.B 053 Abakaliki \\ Ebonyi State, Nigeria.
}

\begin{abstract}
Water related poverty among farm households in Ebonyi State, Nigerian was studied. Multi-stage random sampling technique was used to select a total of 180 respondents. Primary data were collected with the use of structured questionnaire and interview schedule and analyzed with descriptive and inferential statistical tools. The result of the study shows that more males participated in agriculture than females. Analysis also indicated that majority of the farm households live below poverty line with about two-third (68.1\%) of the farmers' mean per capita household income spent on food alone and one-third (31.8\%) of the income on non-food items such as education, accommodations, clothing and transformation. The poverty indicator analysis shows that there was incidence of water borne diseases, infant mortalities, and poor primary school enrolment among others in the study area. The result also shows that the farmers were very poor and lacking in basic necessities of life. The results of the cross tabulation analysis, chisquare and multiple regression show that there was significant relationship between poverty indicator variables and water supply gap among the Farm households in the study area. It was recommended that Federal, State and Local Governments should consider water provision to the rural areas as top priority. This will reduce the incidence of water borne diseases, enhance the economic performance of the farmers, increase their productivity, and thus reduce poverty in the study area.
\end{abstract}

Keywords- Water, Related, Poverty, Farm Households, Ebonyi State.

\section{INTRODUCTION}

Water is linked with food production, household activities, industrial production and environment sustainability. Water for agriculture is critical for food security. F.A.O (1996) stated that between 50 and 60 percent of all the food production required to meet current food demands up to the year 2035 will have to be met through irrigation. It is estimated that sixty percent of future cereal production will come from irrigated areas, increasing water scarcity will be a primary cause of the slowdown in projected irrigated cereal yield growth in developing countries (Rosegrant and Cai, 2001). In the 2003 and 2004 seasons, irrigated grain production contributed to 0.9 percent of the total grain, while that of vegetable production contributed to 2.3 percent of the total vegetable production in Nigeria (Enplan, 2004). Ebonyi State has irrigation potential of 66,710 hectares with estimated water requirement of 333,550,000 cubic meters (Ebonyi State Ministry of Agriculture, 2005).

Water is also essential for house needs and access to safe drinking water and sanitation is critical to maintaining health particularly for children. It is estimated that about 3900 children die every day from water borne diseases (World Health Organization, 2004). In Ebonyi State, the situation is disturbing where in 2003 and 2004, a total of 11,685 diarrhea cases with 36 deaths were reported, a total of 126 guinea worn cases were equally reported, while a total of 207 cholera cases with 16 deaths and a total of 194 typhoid related diseases with 11 death were further reported, and those mostly affected were children (Ministry of Health Ebonyi State, 2005). According to global water supply and sanitation assessment 2000 report, the majority of the world's population without access to improved water supply or sanitation services live in Africa and Asia. The situation is much more profound in Nigeria where less than 50 percent of the population has access to safe drinking water and sanitation (Core welfare indicator survey, 2006). It has been predicted that the world population will grow to 8 billion by 2020 , with more of the increases occurring in urban areas, by 2025 in rural areas additional one billion people will need water supply and 2.1 billion will need sanitation (Damme, 2001). This expected increase has raised considered fear and debate about the world's ability to meet the future water need and food security. The future of water availability is highly uncertain, and some of these uncertainties are due to relatively uncontrollable factors such as climate change. Other critical factors such as population growth, investment in water infrastructure, allocation of water to various uses, reforms in water management and technological change 
in agriculture, can be controlled by choices made collectively by world's people (Rosegrant et al, 2001).

Water insecurity has many repercussions on household's health, economy and productivity. Lack of access to safe water supply has been identified as one of the leading causes of poverty. According to World Water Development Report (WWDR $)_{1}$, (2003) problems of poverty are inextricably linked with those of water, its availability, proximity, quantity and quality.

Water security is access by all individual at all times to sufficient and safe water for a healthy and productive life (webb.1998). Household water demand refers to water withdrawal and consumption, while household water supply refers to water availability and accessibility (Rosegrant, Cai and Cline, 2002).

Water demand and supply gap is the breaching of absolute minimum of 20 litres of water per capita per day of water supply to either urban or rural households (WHO, UNICEF, 2005). In view of the above, and owing to limited information and knowledge about the supply gap of water in Ebonyi State and how it is related to poverty profile of the rural farm households in the State, this study becomes necessary. The questions are. How can the problems of water insecurity be addressed, even as the demand for water by all users grows as a result of increase in population? What are the socio-economic characteristics of the farmers in the study area? What is the level of poverty among the respondents in the study area? Is there any connection between water scarcity and the poverty profile of the rural farmers in the State?

\subsection{Objectives of the Study}

The broad objective was to assess the incidence of water related poverty among the farm households in Ebonyi State. The specific objectives were to:

i. analyze the socio-economic characteristics of the farm households in the study area.

ii. determine the poverty level of the respondents in the study area.

iii. ascertain the poverty indicator variables of the respondents in the study area

iv. establish the relationship between the poverty indicator variables of the farm households with water supply gap in the study area.

\subsection{Hypothesis}

A null hypothesis was tested

$\mathrm{H}_{\mathrm{o} 1}$ : There is no significant relationship between the poverty indicator variables and water supply gap of the farm households in the study area.

\section{METHODOLOGY}

The entire Ebonyi State was the study area. The State is made up of 13 L.G.As with a total landmass of
$7,087.12 \mathrm{~km}^{2}$ and estimated population of 2,198,371 (NPC, 2006). The occupation of the people is predominantly farming. The State is geologically of basement complex with springs and streams majorly seasonal. High yielding motorized boreholes are not possible (Ebonyi State Rural Water and Sanitation Agency, 2005). Multi-stage random sampling technique was used for the selection of the respondents used for the study.

Stage1: Two L.G.As were selected at random from each of the three Agricultural Zones of the State making a total of six L.G.As.

Stage2: This involved the selection of three communities at random from each of the six L.G.As. This gave a total of 18 communities in all.

Stage3: Ten farm households were selected at random from each of the 18 communities making a total of 180 Respondents who were used for the study.

Primary data were collected with a well structured questionnaire and oral interview schedule administered to the Respondents. Both descriptive and inferential statistics were used in analyzing the data. Descriptive statistics such as frequency counts and mean per capita household expenditure, were used to analyze objectives (i),(ii) and (iii) and percentage, mean, cross tabulation, $\mathrm{x}^{2}$ and multiple regression were used to analyze objective, (iv)

\subsection{Model Specification}

Model for multiple regression analysis that related poverty indicator variables to water supply gap was stated as:

$y=f\left(x_{1} x_{2} x_{3} x_{4} x_{5} x_{6} x_{7}\right) \ldots \ldots \ldots$ implicit form

$\mathrm{y}=\mathrm{a}_{\mathrm{o}}+\mathrm{a}_{1} \mathrm{x}_{1}+\mathrm{a}_{2} \mathrm{x}_{2}+\mathrm{a}_{3} \mathrm{x}_{3}+\mathrm{a}_{4} \mathrm{c}+\mathrm{a}_{5} \mathrm{x}_{5}+\mathrm{a}_{6} \mathrm{x}_{6}+\mathrm{a}_{7}$

$\mathrm{x}_{7}+$ et....explicit form

Where

$\mathrm{Y}=$ Water supply gap (below 20 liters per capital per day)

$\mathrm{x}_{1}=$ Farm Household Food insecurity(number of farm households below the minimum level of dietary energy consumption).

$\mathrm{X}_{2}=$ Distance to nearest medical service $(\mathrm{km})$

$\mathrm{X}_{3}=$ Inability to pay for medical services (naira)

$\mathrm{X}_{4}=$ Adult Illiteracy (percentage of farm household heads that have no formal education).

$\mathrm{X}_{5}=$ Infant mortality (number of death of infants under five years

of age for the last ten years: 2004-2014).

$\mathrm{X}_{6}=$ Water related diseases (number of water borne diseases

suffered for the last ten years: 2004-2014)

$\mathrm{X}_{7}=$ Primary school enrolment

$\mathrm{b}_{\mathrm{o}}=$ constant 
$\mathrm{b}_{1}-\mathrm{b}_{7}=$ coefficients of regression

Model for chi square $\left(\mathrm{x}^{2}\right)$ analysis that related poverty indicator variables to water supply gap was stated as;

$$
\mathrm{x}^{2}=\frac{\sum(0-\mathrm{e})^{2}}{\mathrm{e}}
$$

Where:

$$
\begin{aligned}
& \mathrm{x}^{2}=\text { chi-square } \\
& \qquad \begin{aligned}
\sum & =\text { summation } \\
\mathrm{o} & =\text { observed frequency } \\
\mathrm{e} & =\text { expected frequency }
\end{aligned}
\end{aligned}
$$

\subsection{Test of Hypothesis}

F-test and $\mathrm{x}^{2}$ - test were used to test the hypothesis at $5 \%$ level of significance. These were expressed thus:

$$
\begin{aligned}
& \text { i. } \quad \mathrm{F} \text {-calc }=\mathrm{R}^{2}(\mathrm{~N}-\mathrm{K}) \\
& \text { I- } \mathrm{R}^{2}(\mathrm{~K}-1)
\end{aligned}
$$

Where:

$\mathrm{R}^{2}=$ coefficient of multiple determination

$\mathrm{N}=$ sample size

$\mathrm{K}=$ number of variable

Decision Rule: if f-cal $>\mathrm{f}$-tab. reject the null hypothesis, otherwise accept its alternative, and if $x^{2}-c a l>x^{2}-t a b$ reject the null hypothesis, otherwise accept it's alternative.

\section{RESULTS AND DISCUSSION}

The results and discussion were done according to the specific objectives of the study.

3.1 Socio-economic Characteristics of Farmers in the

\section{Study Area.}

\begin{tabular}{|c|c|c|}
\hline \multicolumn{3}{|l|}{ Educational level } \\
\hline Non formal education & 18 & 10. \\
\hline Primary education & 43 & 23.30 \\
\hline Secondary education & 71 & 39.44 \\
\hline Tertiary education & 50 & 27.80 \\
\hline \multicolumn{3}{|l|}{ Household size } \\
\hline $1-3$ & 57 & 31.70 \\
\hline $4-6$ & 102 & 56.70 \\
\hline $7-8$ & 12 & 6.70 \\
\hline 9 and above & 9 & 5.00 \\
\hline \multicolumn{3}{|l|}{ Farming system } \\
\hline Livestock farming & 5 & 2. 80 \\
\hline Mixed farming & 94 & 52.00 \\
\hline Food crop farming & 81 & 45.20 \\
\hline \multicolumn{3}{|l|}{ Farm size in Hectares } \\
\hline Less 1 & 54 & 30.00 \\
\hline $2-3$ & 53 & 29.40 \\
\hline $4-6$ & 41 & 22.80 \\
\hline $7-9$ & 22 & 12.20 \\
\hline Above 9 & 10 & 5.60 \\
\hline \multicolumn{3}{|l|}{ Annual farm income } \\
\hline Less than 50,000 . & 61 & 33.90 \\
\hline $51,000-100,000$. & 46 & 25.60 \\
\hline $101,000-200,000$. & 42 & 23.30 \\
\hline Above 200.000 & 31 & 17.20 \\
\hline
\end{tabular}

Analysis of socio-economic characteristics of the farmers was carried out with frequency counts and percentages and result was presented in table1.

Table.1: Frequency distribution of the Respondents based on their Socio-economic Characteristics in the study area

$\begin{array}{ccc}\begin{array}{c}\text { Socio- economic } \\ \text { characteristics } \\ \text { Gender }\end{array} & \begin{array}{c}\text { Frequency } \\ \mathbf{( 1 8 0 )}\end{array} & \begin{array}{c}\text { Percentage } \\ \mathbf{( 1 0 0 )}\end{array} \\ \text { Male } & 137 & 76.00 \\ \text { Female } & 43 & 24.00 \\ \text { Age } & & \\ 24-30 & 28 & 15.60 \\ 31-40 & 40 & 22.20 \\ 41-50 & 42 & 23.30 \\ 51-60 & 31 & 17.20 \\ >60 & 39 & 21.70 \\ \text { Marital Status } & & \\ \text { Married } & 156 & 86.60 \\ \text { Single } & 24 & 13.40\end{array}$

Source: Field Survey, 2014

Table 1 show that $76.7 \%$ of the respondents were males, while $23.3 \%$ of them were females. This is in line with the Poverty Profile Report of 2005 which indicated that gender wise, more males participate in agriculture than the females and also, the World Water Development Report $_{4}$ (2012) hinted that $43 \%$ of farmers in the developing countries are females.

Majority of the respondents represented by $23.3 \%$ were in the age range of $41-50$ years, while $17.2 \%$ of them were in the age range of 51-60. This reveals that farming in the study area did not attract the participation of the youths. This led to poor agricultural productivity in the study area. The majority of the respondents represented by $86.6 \%$ were married, while $13.4 \%$ of them were single. This shows that more married respondents participated in agriculture than the singles respondents. Married people have greater family responsibilities and they seek various means of meeting the need of their families.

The majority of the farmers represented by $38.9 \%$ had primary education while $10 \%$ of the respondents had no formal education. This implies that the farmers in the study area had no adequate education to cope with the challenges of modern farming techniques, this affected their productivity and economic performance. The table further shows that the majority of the respondents represented by 56.7 had 4-6 household size, while the 
least of the farmers represented by $5.08 \%$ had 9 members or above, with the average family size of 7 . The high level of household size could be ascribed to the polygamous nature of the farmers in the study area and it is a typical characteristics of peasant farm households, where family members constitute the bulk of the workforce.

The majority of the respondents practised mixed farming, while the least of them were livestock farmers represented by $52.2 \%$ and $2.8 \%$ respectively. This reveals that the farmers in the study area were risk avoiders and adopted the strategy to overcome total farm production failure. The result of the farm size cultivated shows that $30.00 \%$ representing the majority of the respondents cultivated less than 1 hectares of land, whereas the least of the farmers represented by $5.6 \%$ cultivated 9 hectares or above. This implies that the majority of the farmers were really peasants. The result of the annual farm income of the respondents shows that the majority of the farmers represented by $33.9 \%$ earned annual farm income of $\$ 51,000$ or less while the least of them represented by $17.2 \%$ had annual farm income of $\$ 200,000$ and above. This affirms that the farmers in the study area were peasants in all ramifications and could not afford the users' cost of sustainable potable water supply.

\subsection{Poverty level of the Farm Household in the study}

area.

The determination of the poverty profile of the respondents was carried out with Mean Per Capita Household Expenditure or Disposable Income (MPCHHE), percentage, and, frequency count.

Table.2.1:Result of the analysis of Mean Per Capita

\begin{tabular}{|c|c|c|c|}
\hline Item & $\begin{array}{l}\text { Food } \\
\text { poverty } \\
\text { line }\end{array}$ & $\begin{array}{l}\text { Non- } \\
\text { food } \\
\text { poverty } \\
\text { line }\end{array}$ & $\begin{array}{l}\text { General } \\
\text { poverty } \\
\text { line }\end{array}$ \\
\hline \multirow[t]{2}{*}{ MPCHHE } & $N$ & 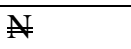 & $N$ \\
\hline & 288,000 & 133.740 & 421.740 \\
\hline Percentage & 68.1 & 31.8 & 100 \\
\hline Ratio & 2 & 1 & 3 \\
\hline
\end{tabular}

Source: Field Survey, 2014

Table 2 shows that the poverty line of the study area was $\$ 421,740$ made up of $\quad$ 288, 000 and N133, 740 poverty line for food and non-food items respectively. The table further shows that $2 / 3$ of the farmers' mean per capita household income representing $68.1 \%$ went for food alone, while $1 / 3$ representing $31.8 \%$ of their income was for non food item like: education, accommodation, transportation, clothing etc. A situation where households spend $2 / 3$ of their disposal income on food alone is unacceptable. This implies that the farmers in the study area were really poor. World Water Development Programme (WWDR) (2012) pointed out that in developing countries rising food cost form a major threat to food security because people spend $100 \%$ of their income on food.

Table.3: Percentage distribution of the Respondents

\begin{tabular}{lll}
\multicolumn{3}{c}{ based on poverty profile. } \\
\hline Variable & $\begin{array}{l}\text { Frequency } \\
\text { ( 180) }\end{array}$ & $\begin{array}{l}\text { Percentage } \\
(\mathbf{1 0 0})\end{array}$ \\
\hline $\begin{array}{l}\text { General } \\
\text { profile }\end{array}$ & & \\
aboverty & & 32.8 \\
below poverty line & 121 & 67.2 \\
line poverty & &
\end{tabular}

$\begin{array}{lll}\begin{array}{ll}\text { Food consumption } \\ \text { poverty line }\end{array} & & \\ \quad \text { above food poverty } & 113 & 37.2 \\ \text { line } & & 62.8 \\ \quad \text { below food poverty } & & \\ \text { line } & & \end{array}$

\begin{tabular}{lll}
$\begin{array}{l}\text { Non-food poverty } \\
\text { line }\end{array}$ & 51 & 28.3 \\
above the line & 129 & 71.7 \\
below the line & & \\
\hline
\end{tabular}

\section{Source Field Survey 2014}

The result of table 3 shows that majority of the respondents represented by $67.2 \%$ were below the poverty line, implying that the farmers in the study area were poor.

According to Poverty Profile Report (2005), Poverty in Nigeria is a rural phenomenon where agricultural activities are most predominant. The result of food consumption shows that $62.8 \%$ of the respondents were below the minimum level of dietary energy consumption. This implies that they had no access to food. FAO (2009) observed that hunger is the greatest world tragedy and scandal and it is definitely not acceptable. It further stated that hunger is a consequence of poverty and it is one of its causes. IFAD and UNEP (2013) declared that access to adequate food in the rural areas of developing counties depends heavily on access to natural resources including water, that are necessary to produce food.

The result of the non-food poverty line indicates that $71.1 \%$ of the farmers were below the poverty line. This implies that the farmers in the area lacked other basic necessities of life as clothing, accommodation, education etc. 
3.3 Poverty Indicator variables of the respondents

Table.4: Percentage distribution of the respondents based on the poverty indicator variables:

\begin{tabular}{lll}
\hline Variables & Frequency & Percentage \\
& 180 & $\%$ \\
\hline
\end{tabular}

\section{Food consumption}

above food poverty line

below food poverty line

$\begin{array}{ll}67 & 32.2 \\ 113 & 62.8\end{array}$

Access to medical service

a. Distance to nearest hospital in 200 metre less 200 metres 51 above 200 metres $\quad 129$

b. Ability to pay for medical services able

unable

\section{Primary school enrollment}

0

$1-2$

3-4

Water related disease suffered for the last ten years (2004-2014)

$\begin{array}{lll}\text { Cholera } & 24 & 13.3 \\ \text { Dysentery } & 32 & 18.0 \\ \text { Typhoid } & 40 & 22.2 \\ \text { Guinea worm } & 8 & 4.4 \\ \text { Hepatits } & 11 & 6.0 \\ \text { Malaria } & 60 & 33.0 \\ \text { Trachoma } & 2 & 1.1 \\ \text { schistosomiasis } & 3 & 2.0\end{array}$

\section{Infant mortality suffered} for the last ten years

$\begin{array}{lll}\mathbf{( 2 0 0 4 - 2 0 1 4 )} & 10 & 5.6 \\ 0 & 132 & 73.3 \\ 1-2 & 21 & 11.70 \\ 3-4 & 17 & 9.40\end{array}$

Above 5

\section{Source: Field Surrey, 2014}

The result of the food consumption analysis shows that $62.8 \%$ of the respondents in the study area had no access to adequate dietary nutrition. This is unacceptable because of the fact that the respondents were predominantly farmers. This is in line with the finding of IFAD (2011) which observed that $65 \%$ of Nigerians that are food insecure live in the rural areas where agriculture is practised.

The result of access to medical services shows that $77.1 \%$ of the farmers cover a distance of more than 200 metres to access their medical centers, while $70 \%$ of them were not able to pay for medical services. This implies that the farmers had not access to Medicare and it is an indication of poverty. This is in line with the finding of Core Poverty Indicator Survey (2006) which put access to Medicare in Ebonyi State at $17.3 \%$.

The result of the primary school enrollment indicates that $40.6 \%$ of the farmers in the study area did not have any of their children enrolled in primary school, while $13.3 \%$ of them had 5 children and above enrolled in primary school. This reveals that there was poor primary school enrollment in the study area. One of the problems of water poverty is that children fetch water instead of attending school, time spent carrying water is time missed from school lessons (Living Water Africa, 2014).

The result of water related disease suffered by the respondents in the area for the last ten years indicates that the majority of the farmers in the study area represented by $33 \%$ suffered malaria followed by typhoid represented by $22 \%$. The result further shows that all the farm households in the area suffered water related diseases. This implies that water borne diseases were prevalent in the area and this is an indication of water scarcity and poverty. World Bank (1985) pointed that those households whose conditions of life are so degraded by diseases, illiteracy, malnutrition and equally without the basic necessities of life are said to live in absolute poverty.

The result of the infant mortality suffered by the farmers in the area for the last ten years shows that $73.3 \%$ of the respondents in the area recorded between 1and 2 infant mortalities, while $5.6 \%$ of the farmers did not record any infant mortality for the last ten years. This was as a result of farmer's lack of access to clean water and medical services in the study area and it is a cardinal indicator of poverty. $\mathrm{WWDR}_{3}$ (2009) stated that in areas poorly served with water and sanitation, the child mortality is multiplied by 10 or 20 compared to the area with adequate water and sanitation services. WHO (2014) pointed out that 3,900 children in the rural areas of the developing countries die every day from water born diseases.

3.4 The relationship between the Water Poverty indicator Variables and water supply gap 


\begin{tabular}{|c|c|c|c|c|}
\hline \multirow[t]{3}{*}{ Poverty indicator variables } & \multirow{2}{*}{\multicolumn{2}{|c|}{$\begin{array}{l}\text { Potable water supply gap in }(\mathrm{L}) \\
\text { per capita per day }\end{array}$}} & \multirow{3}{*}{$\begin{array}{l}\text { Freq } \\
180\end{array}$} & \multirow{3}{*}{$\begin{array}{l}\text { per } \\
100\end{array}$} \\
\hline & & & & \\
\hline & Below 20(L) & Above 20(L) & & \\
\hline \multicolumn{5}{|l|}{ Food Consumption } \\
\hline Food insecure (FHhs) & 64(56.6) & 49(43.4) & 113 & 100 \\
\hline Food secure (FHhs) & $30(44.8)$ & $37(55.2)$ & 67 & 100 \\
\hline \multicolumn{5}{|l|}{ Medicare } \\
\hline No access to Medicare & $75(56)$ & $57(44)$ & 129 & 100 \\
\hline Access to Medicare & $13(25.5)$ & $38(74.5)$ & 51 & 100 \\
\hline \multicolumn{5}{|l|}{ Primary Schl. Enrollment } \\
\hline Zero $(0)$ enrollment & $19(26.30)$ & $54(73.7)$ & 73 & 100 \\
\hline $1-2$ & $26(46.4)$ & $29(53.6)$ & 55 & 100 \\
\hline $3-4$ & $17(61.0)$ & $11(39.0)$ & 28 & 100 \\
\hline Above 4 “ & $22(90.3)$ & $2(9.7)$ & 24 & 100 \\
\hline \multicolumn{5}{|c|}{ Water Related Diseases (2004-2014) } \\
\hline $1-2$ & $34(37.8)$ & $56(62.2)$ & 90 & 100 \\
\hline 3-4 & $50(67.8)$ & $26(26.2)$ & 76 & 100 \\
\hline $5-6$ & 11(78.6) & $3(21.4)$ & 14 & 100 \\
\hline \multicolumn{5}{|l|}{ Infant mortality (2004-2014) } \\
\hline 0 & $3(42.4)$ & $7(57.6)$ & 10 & 100 \\
\hline $1-2$ & $76(57.6)$ & $56(42.4)$ & 132 & 100 \\
\hline 3-4 & $6(75.4)$ & $5(24.6)$ & 21 & 100 \\
\hline Above 4 & 17(100) & - & 17 & 100 \\
\hline \multicolumn{5}{|l|}{ Adult literacy level } \\
\hline No formal education & $10(55.6)$ & $8(44.4)$ & 18 & 100 \\
\hline Primary education & $60(66.6)$ & $30(33.4)$ & 90 & 100 \\
\hline Secondary education & 20(37.7) & $33(62.3)$ & 53 & 100 \\
\hline Tertiary education & $5(6.3)$ & $14(73.7)$ & 19 & 100 \\
\hline
\end{tabular}

Source: Field Surrey, $2014 \quad$ NB: Figurers in bracket are Percentages

The result of the Cross tabulation shows that $56.6 \%$ of the farm households that had no access to food security had less than 20 liters of water supply per capital per day while $55.2 \%$ of the food secured respondents had more than 20 liters per capital per day water supply. This implies that food insecurity is related to water insecurity, while food security is otherwise linked with water security. Access to adequate food in the rural area of developing countries depends heavily on access to natural resources including water (IFAD and UNEP, 2013).

The result of the access to medical services in the study area reveals that $56 \%$ of the farmers that had no access to medical services had less than 20 liters per capita water supply while $44 \%$ of the respondent had over 20 liters of water supply. Moreover those respondents that had access to medicare represented by $74.5 \%$ had 20 litres and above water supply. This implies that there is a relationship between the farmer's access to water and their access to medicare in the study area. The higher the water insecurity the higher their level of inability to access Medical services in the study area. This shows that water insecurity affected the productivity and the economy of the farmers in the study area.

The result from the primary school enrollment indicates that the majority of the respondents that had zero primary school enrollment represented by $73.7 \%$ had more than 20litres water supply, while $26.3 \%$ had less than 20 liters water supply. The majority of the farmers that had 4 children or more enrolled in primary school represented by $90.3 \%$ had less than 20litres per capita daily water supply while $9.7 \%$ of then had above 20litres water supply. This implies that the higher the primary school 
enrollment the higher the farm household water insecurity and the less the primary school enrollment the less the water insecurity. This shows that primary school enrollment is inversely related to the respondents' access to water in the study area. The poor primary school enrollment in the study area as one of the findings of this work is as a result of pupils sacrificing school attendance to water fetching.

Water related diseases result shows that the majority of the farmers in the study area represented by $62.2 \%$ that suffered 1-2 water related diseases had above 20litres per capita per day water supply, while $37.8 \%$ of them had less than 20litres. Similarly, the majority of the respondents represented by $78.6 \%$ that suffered 5-6 water related disease had less than 20litres per capita per day water supply while $21.4 \%$ of them had more than 20litres. This implies that the higher the water insecurity the higher the water related disease prevalence in the study area.

The result of the infant mortality revealed that the majority of the respondents represented by $57.2 \%$ had 20litres and more per capita per day water supply, while $42.4 \%$ of them had less than 20liters per capita per day water supply. The respondents that recorded 4 and above infant mortalities represented by $100 \%$ had less than 20litres of water supply per capita per day. This implies that infant mortality is directly related to water insecurity and inversely related to water security of the respondents in the study area.

The adult literacy level result indicates that the majority of the farmers that had no formal education represented by $55.6 \%$ had less them 20 litres per capita per day water supply, while $44.4 \%$ of them had 20litres and more water supply per capita per day. The majority of the farmers in the area that had tertiary education represented by $73.7 \%$ had 20litres and above per capita per day water supply, while $26.3 \%$ of them had less than 20litres of daily water supply. This implies that education is directly related to water security, while illiteracy is related to insecurity of water of the respondents in the area.

Table.6: Multiple Regression Result relating poverty indicator variables to potable water supply gap in liters

\begin{tabular}{|c|c|c|c|c|}
\hline $\begin{array}{l}\text { Var } \\
\text { iabl } \\
\text { es }\end{array}$ & Variable name & $\begin{array}{l}\text { Regres } \\
\text { sion } \\
\text { co- } \\
\text { efficie } \\
\text { nt }\end{array}$ & $\begin{array}{l}\text { Stan } \\
\text { dard } \\
\text { erro } \\
\mathrm{r}\end{array}$ & $\begin{array}{l}\mathrm{t}- \\
\text { valu } \\
\mathrm{e}\end{array}$ \\
\hline $\mathrm{B}_{\mathrm{o}}$ & Constant & 46.2 & 14.9 & $\begin{array}{l}3.10 \\
0^{*}\end{array}$ \\
\hline $\mathrm{X}_{1}$ & Food consumption & 5.2 & 2.3 & $\begin{array}{l}2.26 \\
1 * *\end{array}$ \\
\hline $\mathrm{X}_{2}$ & $\begin{array}{l}\text { Distance to health } \\
\text { centre }\end{array}$ & 4.4 & 52.1 & $\begin{array}{l}2.09 \\
5 * *\end{array}$ \\
\hline$X_{3}$ & Adult literacy & 59.9 & 8.25 & 7.26 \\
\hline
\end{tabular}

\begin{tabular}{|c|c|c|c|c|}
\hline $\mathrm{X}_{4}$ & Infant mortality & 19.7 & 4.30 & $\begin{array}{l}4.58 \\
1 *\end{array}$ \\
\hline $\mathrm{X}_{5}$ & $\begin{array}{l}\text { Water related } \\
\text { disease }\end{array}$ & 11.8 & 3.65 & $\begin{array}{l}3.23 \\
2 *\end{array}$ \\
\hline$X_{6}$ & $\begin{array}{l}\text { Primary school } \\
\text { enrolment }\end{array}$ & 30.2 & 8.50 & $\begin{array}{l}3.55 \\
*\end{array}$ \\
\hline$X_{7}$ & $\begin{array}{l}\text { Ability to pay for } \\
\text { medical services. }\end{array}$ & 7.9 & 3.75 & $\begin{array}{l}2.10 \\
0 * *\end{array}$ \\
\hline $\begin{array}{l}=\mathrm{si} \\
.78\end{array}$ & $\begin{array}{l}\text { int at } 1 \% \text { level o } \\
\text { cant at } 5 \% \text { level } \\
\text { ficant at } 10 \% \text { lev } \\
78.6 \%)\end{array}$ & $\begin{array}{l}\text { robabi } \\
\text { robab } \\
\text { f pro }\end{array}$ & & \\
\hline
\end{tabular}

Adjusted $\mathrm{R}^{2}=\overline{0} .656(65.1 \%)$

$\mathrm{F}=$ value $=2.708 * *$

\section{Source: Data Analysis, 2014}

The result of multiple regression analysis presented in table 6 indicates that the coefficient of multiple determination $\mathrm{R}^{2}$ was $78.6 \%$ and adjusted $\mathrm{R}^{2}$ was $65.1 \%$. This means that about $78.6 \%$ variation in level of water scarcity in the study area was caused by combined relationship of poverty indicators of the sampled respondents. The high value $\mathrm{R}^{2}(78.6 \%)$ signified that the poverty indicators of the farmers has significant relationship to the level of their inaccessibility to potable water in the study area and this was confirmed by the positive co-efficient of the independent variables adopted in the regression model. The closeness of adjusted $\mathrm{R}^{2}$ $(65.16 \%)$ to $R^{2}(78.6 \%)$ in numerical value indicates that the explanatory power of the regression was not exaggerated. Also, the overall significant relationship of the poverty indicators of the farmers on the level of potable water scarcity shown by the high value of F-ratio (2.708), which was statistically significant at $5 \%$ $\left(0.016^{* *}\right)$ was statistically reliable.

The coefficient of food consumption $\left(\mathrm{x}_{1}\right)$, distance to the nearest health centre and ability to pay for medical services were statistically significant at $5 \%$ bearing positive signs. This implies, that they had positive relationship to the respondents level of water supply gap and their a priori expectations were met.

Adult literacy $\mathrm{x}_{3}$, infant mortality $\mathrm{x}_{4}$, water related disease $\mathrm{x}_{5}$ and primary school enrolment $\mathrm{x}_{6}$ were all significant at $1 \%$ and they all bore positive signs, implying that they all had positive relationships with clean water supply gap in the study area.

Table.7: $X^{2}$-test result of water poverty indicator variables in relation to water supply gaps.

\begin{tabular}{lllll}
$\begin{array}{l}\text { Poverty } \\
\text { Indicators }\end{array}$ & $\mathbf{X}^{\mathbf{2}}$ cal & $\mathbf{X}^{\mathbf{2}}$ tab & Df & Significance \\
\hline Food & 9.20885 & 2.5000 & 2 & $1 \%$
\end{tabular}




\begin{tabular}{|c|c|c|c|c|}
\hline \\
\hline \multicolumn{5}{|l|}{$\begin{array}{l}\text { consumption } \\
\text { Access to } \\
\text { medicare }\end{array}$} \\
\hline $\begin{array}{l}\text { Pr. Sch. } \\
\text { enrolment }\end{array}$ & 50.600 & 15.0883 & 5 & $1 \%$ \\
\hline $\begin{array}{l}\text { Water related } \\
\text { diseases }\end{array}$ & 17.200 & 11.3449 & 3 & $1 \%$ \\
\hline $\begin{array}{l}\text { Infant } \\
\text { mortality }\end{array}$ & 16.9000 & 15.0883 & 5 & $1 \%$ \\
\hline $\begin{array}{l}\text { Adult } \\
\text { illiteracy } \\
\text { level }\end{array}$ & 12.6005 & 9.48772 & 4 & $5 \%$ \\
\hline
\end{tabular}

Source: Data Analysis, 2014.

Table 7 shows that the $X^{2}$ results of the poverty indicator variables in relation to water supply gap were all significant. This confirms that there is a linkage between poverty indicator variables of the respondents with water scarcity.

\subsection{Test of Hypothesis}

$\mathrm{H}_{01}$ : The null hypothesis which states that the water poverty indicator variables of the farmers have no significant relationship with the level of clean water supply gap in the study area was tested using $\mathrm{X}^{2}$-test and F- test statistics under 0.05 level of significance. The tests were significance at $5 \%$ level of probability leading to the rejection of the null hypothesis and the acceptance of the alternative hypothesis which affirms that there is a significant relationship between the poverty indicator variables and the level of water supply gap in the study area.

\section{CONCLUSION AND RECOMMENDATIONS}

The study has shown that the farmer's poverty level in the study area has a strong relationship with clean water supply gap. Water scarcity also adversely affected the health, the productivity and the economic performance of the respondents in the study area. It was recommended that government should articulate and integrate rural water provision into the mainstream of her policy framework. This will increase food production, and impacts positively on the health and the economy of the farmers in the rural area and thus reduce hunger and poverty.

\section{REFERENCES}

[1] Damme, H.V 2001: Domestic Water Supply Hygiene and Sanitation. Focus 9 Brief 3 of 14 October. A 2020 Vision for Food, Agriculture and Environment IFPRI-Washington, D.C.

[2] Ebonyi State Ministry of Agriculture and Natural Resources (2009): Irrigation Project Report.
[3] Ebonyi State Ministry of Health (2005): Epidemiology Department Annual Report.

[4] Ebonyi State Rural Water Supply and Sanitation Agency (2010): Report on the total Boreholes drilled (2002-2010).

[5] Enplan Group (2004): Review of Public Irrigation Sector in Nigeria. Draft Final Report of Project. UTF/046/MR/UTF.

[6] Food and Agricultural Organization (FAO) 2013: Sustainable Food System for Food Security.

[7] FAO (2008): The Right to Food and Access to Natural Resources.

[8] FAO (2000): The State of Food Security in the World.

[9] Global Water Analysis and Assessment Report 2012): UN-Water Analysis and Assessment www. Un.org/water for life decade/pdf/g...

[10] International Fund for Agricultural Development (IFAD) (2013): Sustainable Food System for Food Security and Nutrition.

[11]IFAD and UNEP (2013): Enabling Poor Rural to Overcome Poverty Smallholders Food Security and the Environment.

[12] National Bureau of Statistics (2001): Poverty Profile for Nigeria (1994-2005).

[13] National Bureau of Statistic (2006): Core Welfare Indicator Survey Nigeria

[14] National Population Commission (2006): Analytical Report.

[15] Omonona, B.T (2014): Managing Nigerian Water Resources to Reduce Poverty. Journal of Economics and Sustainable Development Vol. 2-No 4. 2011154.

[16] Pacific Institute Research for People and the Planet (2013): Water and Poverty in Africa.

[17] Rosegrant, M.W and Cai, A (2001): Water for Food Production. Brief No 2 in 2020 Focus 9. Overcoming Water Scarcity and Quality Constraint. IFPRI Washington D.C.

[18] Rosegrant, M.W Cai, A, Sera and Cline (2002): Global Water Outlook to 2005. Averting an Impending Water Crisis. IFPRI-Washington D.C.

[19] United Nation Environmental Protection (UNEP) (2009): The Environment Role in Averting Future Food Crisis.

[20] UNICEF (2012): Progress on Drinking Water and Sanitation. www.unicef.org/jmp report 2012/Pdf.

[21]UNICF (2010): Water, Sanitation and Hygiene www.unicef.org/wash/.

[22] World Bank (2011): Bringing Water to African Poor http//beta, dateworldbank.Org.

[23] World Bank (2011): Food Insecurity in Nigeria.

[24] World Bank (1985): Taking Action to Reduce Poverty in Sub-Saharan African. Washington D.C.> 
http//www.worldbank.

org.afri.findings/interbarg/inforb 13 am.Htm.10k>.

[25]World Health Organization (2010): Healthy Environment for Healthy Children $3^{\text {rd }}$ WHO International Conference on Children's Health and the Environment.

[26] WHO (1996): Water and Sanitation Fact Sheet No 112 Geneva WHO. http // www water org/ asset/pdf/factsheet 112/pdf

[27]World Water Development Report 4 (2012):Water and Food Security: www.Fao.Org.

[28]WWDR 3 (2009): Water in Changing World. www.unesco.Org/water/wwap/wwdr/Wwdr.

[29] WWDR , (2003): Water for People, Water for Life. www. unesco.Org/water/wwap/wwdr/wwdr $r_{1}$. 